\title{
Quality characteristics of porridge made from different Korean rice varieties including high yield tongil-type rice
}

\author{
Eun-Yeong Sim ${ }^{1 *}$, Ji Yoon $\mathrm{Lee}^{2}$, Jun Hyeon $\mathrm{Cho}^{2}$, Mi-Ra Yoon ${ }^{1}$, Ji-eun Kwak ${ }^{1}$, \\ $\mathrm{Nam}^{-G e o l ~ K i m}{ }^{1}$, Yong-hee Jeon ${ }^{1}$, Choon-Ki Lee ${ }^{1}$, Jeom Sig Lee ${ }^{3}$, Ha-Cheol Hong \\ ${ }^{1}$ Post-Harvest Technology Division, National Institute of Crop Science, RDA, Suwon 16613, Korea \\ ${ }^{2}$ Paddy Crop Research Division, National Institute of Crop Science, RDA, Milyang 50424, Korea \\ ${ }^{3}$ Division for Korea Program on International Agriculture, RDA, Jeonju 54875, Korea
}

\section{다수성 통일형을 포함한 벼 품종이 쌀미음 품질특성에 미치는 영향}

\author{
심은영 ${ }^{1 *} \cdot$ 이지윤 ${ }^{2} \cdot$ 조준현 ${ }^{2} \cdot$ 윤미라 $^{1} \cdot$ 곽지은 $^{1} \cdot$ 김남걸 $^{1} \cdot$ 전용희 $^{1} \cdot$ 이춘기 $^{1} \cdot$ 이점식 $^{3} \cdot$ 홍하철 $^{1}$ \\ 1농촌진흥청 국립식량과학원 수확후이용과, ${ }^{2}$ 농촌진흥청 국립식량과학원 논이용작물과, \\ ${ }^{3}$ 농촌진흥청 기술협력국 국외농업기술과
}

\begin{abstract}
This study was carried out to compare the physiochemical properties and quality characteristics of porridge made from different Korean rice varieties, including high yield tongil-type rice. The rice varieties used in this study were 4 tongil-type (Areum, Namcheon, Hanareum3, Hanareum4) and 5 japonica-type rices (Unkwang, Daebo, Goami4, Dodamssal and Hwaseonchal). The protein and amylose contents of the varieties ranged from $6.0 \%$ (Namcheon) to $7.3 \%$ (Hanareum3) and from $5.0 \%$ (Hwaseonchal) to $42.8 \%$ (Dodamssal). Compared to the other varieties, Hwaseonchal and Dodamssal had low final and setback viscosity values in the rapid-visco analyzer test. The color value of the poridge ranged between 52.90 and $\mathbf{7 1 . 1 2}$ for the $L$ value, $-\mathbf{2 . 0 6}$ and $-\mathbf{1 . 0 1}$ for the a value, and $\mathbf{- 5 . 5 9}$ and $\mathbf{- 2 . 6 2}$ for the $b$ value. SEM images revealed distinct differences in the endosperm structure of rice varieties as well as the porridge. Furthermore, ponidge made from Hwaseonchal rice had the highest spreadability, followed by porridge made from others non-glutinous rice varieties, Goami4 rice, and Dodamssal rice. The results of this study suggested that rice varieties with different amylose contents could be effectively used to control the viscosity of rice porridge. In laboratory experiments, the sensory test did not indicate significant differences except for the mouthfeel. The mouthfeel of the ponidge depended on the amylose content of rice. This study suggested that tongil-type rice variety such as Hanareum4 could be substituted with Japonica type rice for making porridge.
\end{abstract}

Key words : rice porridge, viscosity, tongil-type rice, variety

\section{서 론}

죽은 곡물의 낟알이나 가루에 물을 많이 넣고 끓여 전분 을 완전히 호화시킨 유동성이 있는 음식의 하나이다(1).

*Corresponding author. E-mail : silvery1225@korea.kr Phone : 82-31-695-0612, Fax : 82-31-695-0609

Received 12 July 2018; Revised 14 August 2018; Accepted 17 September 2018.

Copyright (c) The Korean Society of Food Preservation. All rights reserved.
죽은 식량이 부족할 때 구황음식으로 먹었고, 곡물에 채소 나 산채 또는 동물성 식품을 넣어 약효와 보양효과를 기대 한 제품들이 많이 출시되고 있다(2). 현대사회의 죽은 다이 어트 건강식, 이유식, 환자식의 개념으로도 확대되어, 젊은 세 대뿐만 아니라 모든 연령층에서 소비를 이끌고 있다. 죽 소매시장의 규모는 130 억 원('03), 200 억 원('08), 750 억 원 ('18)으로 시장이 점차 확대되고 있다(3). 쌀을 이용한 죽은 낟알 형태의 일반쌀죽과 낟알을 가루로 분쇄하여 이용하는 쌀미음, 쌀응이 등으로 분류되며, 보통 멥쌀(메벼)을 기본재 료로 만드는 것이 보편적이었다(4). 
그 동안 죽에 대한 연구는 다양한 재료를 이용한 조리방 법 및 이화학적 특성 구명에 대한 내용이 다수를 차지하였 다(5-9). 더불어, 쌀을 이용한 일반죽의 연구로는 난소화성 전분이 많다고 알려져 있는 고아미 2 호를 이용한 연구가 진행된 바 있다(10). 최근 쌀 가공식품에 대한 소비자와 가공업체의 선호도를 조사한 결과, 소비자는 국내산 쌀을 사용한 쌀 가공식품을 선호하고 있으나, 가공업체는 저렴 한 가격의 쌀을 안정적으로 공급받기를 원하고 있는 것으로 나타났다(11). 통일형(tongil-type) 쌀 품종은 일반형 (Japonica-type)과 인디카(Indica rice) 벼를 교잡하여 개발한 품종이다. 이는 일반형보다 단위면적당 쌀 생산량이 높으 나(Table 1), 밥의 찰기가 적고, 질감이 거칠어 밥맛이 좋지 않다고 평가되어 밥쌀용으로는 제 평가를 받지 못하고 있으 며 죽 재료로서는 평가해볼만 한 가치가 있는 것으로 사료 된다. 따라서 본 시험은 다수확 통일형 벼 품종을 포함한 국내산 쌀 9품종을 이용하여 쌀미음 가공적성에 미치는 영향을 평가하였다. 연구결과는 쌀미음에 적합한 원료 쌀 품종 선발 및 개발의 기초자료로 활용될 수 있을 것으로 기대된다.

\section{재료 및 방법}

\section{실험재료}

본 실험에서는 다수성 통일형 벼를 포함한 9 품종을 시험 재료로 선택하였다. 품종은 아름, 남천, 한아름3호, 한아름4 호, 운광, 대보, 고아미4호, 도담쌀, 화선찰(Table 1)이며 2016 년 국립식량과학원에서 생산된 것을 시료로 사용하였다. 현 미기(Model SY88-TH, Ssangyoung Ltd., Incheon, Korea)로 왕겨를 제거한 현미는 정미기(Model MC-250, Wakayama Co., Ltd., Wakayama, Japan)를 이용하여 백미로 도정하였고 분석방법에 따라 가루 시료가 필요한 실험에는 분쇄기 Cyclon mill(CyclotecTM 1093, FOSS Co., Hillerod, Denmark) 로 분쇄하여 $100 \mathrm{mesh}$ 체로 걸러 시료로 사용하였다.

\section{아밀로오스와 저항전분, 단백질 분석}

아밀로스 함량은 Juliano(12)의 비색정량법에 따라 분석 하였다. 분쇄시료 $100 \mathrm{mg}$ 에 $95 \%$ ethanol과 $1 \mathrm{~N}$ sodium hydroxide를 가하고, $100^{\circ} \mathrm{C}$ 에서 호화시킨 후 냉각하였다. 이 호화액에 $1 \mathrm{~N}$ acetic acid와 $2 \% \mathrm{I}_{2}-\mathrm{KI}$ 용액을 첨가하여 정색반응을 시킨 다음, 분광광도계(Evolution 500, Thermo, Madison, WI, USA)를 이용한 $620 \mathrm{~nm}$ 의 파장에서 흡광도를 측정하였다.

품종별 쌀의 저항전분 함량은 Megazyme kit(K-TSTA, Megazyme International Ireland Ltd., Wicklow, Ireland)를 구입하여 분석하였다. 시료 $100 \mathrm{mg}$ 에 pancreatin a-amylase 로 $37^{\circ} \mathrm{C}$ 에서 16 시간 반응 후 침전물에 $2 \mathrm{M} \mathrm{KOH}$ 용액을 첨가하여 분산 및 용해시켰다. $\mathrm{pH} 3.8$ 인 $1.2 \mathrm{M}$ sodium acetate buffer와 amyloglucosidase을 첨가하여 $50^{\circ} \mathrm{C}$ 에서 30 분 반응시킨 후 가수분해된 glucose양에 따라 저항전분을 환산하여 계산하였다.

쌀의 조단백질은 Micro Kjeldahl법에 따라 Foss digester 2020와 자동분석장치(Foss Kjeltec 2400, Foss Tecator, Huddinge, Sweden)로 정량하였다.

\section{쌀가루의 호화점도 특성}

쌀가루의 아밀로그램 특성 분석은 Rapid visco analyzer (RVA-4, Newport scientific, Warriewood, NSW, Australia)를 이용하여 쌀가루 $3 \mathrm{~g}$ 에 $25 \mathrm{~mL}$ 증류수로 현탁액을 만들어 $960 \mathrm{rpm}$ 으로 섞고 $160 \mathrm{rpm}$ 의 plastic paddle 조건에서 $50^{\circ} \mathrm{C}$ 부 터 호화를 시작하여 $95^{\circ} \mathrm{C}$ 까지 상승시킨 후 $50^{\circ} \mathrm{C}$ 로 다시 냉각시키면서 점도를 측정하였다(13).

\section{품종별 미음 제조}

세척한 쌀 $20 \mathrm{~g}$ 을 부피 2 배 분량의 물에 30 분간 수침하였 다. 수침 후 15 분 이상 물 빼기 한 쌀에 기존 쌀 무게 기준의 7배 물을 가하여 homogenizer로 2분 동안 균질화한 후 기타 액체가열기기(RFM-1000, JoyoungOnondo Small Household

Table 1. Characteristics of the grain yield and quality of 4 tongil-type and 5 japonica-type varieties

\begin{tabular}{|c|c|c|c|c|c|c|c|}
\hline Rice type & Variety & Year of development & $\begin{array}{l}\text { Grain shape } \\
(\mathrm{L} / \mathrm{W})^{1)}\end{array}$ & $\begin{array}{l}\text { Grain yield } \\
(\mathrm{kg} / 10 \mathrm{a})\end{array}$ & $\begin{array}{c}\text { Amylose } \\
(\%)\end{array}$ & $\begin{array}{l}\text { Protein } \\
(\%)\end{array}$ & $\begin{array}{c}\text { Resistant starch } \\
(\%)\end{array}$ \\
\hline \multirow[t]{4}{*}{ Tongil-type } & Areum & 1999 & 2.17 & 741 & 19.9 & 6.9 & $\leq 1.0$ \\
\hline & Namcheon & 1995 & 1.79 & 663 & 19.3 & 6.0 & $\leq 1.0$ \\
\hline & Hanareum3 & 2015 & 2.23 & 753 & 18.2 & 7.3 & $\leq 1.0$ \\
\hline & Hanareum4 & 2016 & 2.04 & 797 & 18.5 & 6.9 & $\leq 1.0$ \\
\hline \multirow[t]{5}{*}{ Japonica-type } & Unkwang & 2004 & 1.77 & 586 & 19.1 & 6.2 & $\leq 1.0$ \\
\hline & Daebo & 2011 & 1.67 & 593 & 19.2 & 5.5 & $\leq 1.0$ \\
\hline & Goami4 & 2009 & 1.79 & 453 & 31.8 & 6.9 & $>10.0$ \\
\hline & Dodamssal & 2013 & 1.78 & 529 & 42.8 & 6.7 & $>10.0$ \\
\hline & Hwaseonchal & 1992 & 1.93 & 523 & 5.0 & 6.6 & $\leq 1.0$ \\
\hline
\end{tabular}

${ }^{1)}$ Grain shape $(\mathrm{L} / \mathrm{W})$ was presented as the value of length (L) divided by width $(\mathrm{W})$ of brown rice. 
Appliances Co., Hangzhou, China)로 10분 가열하여 제조 후 $60^{\circ} \mathrm{C}$ 또는 실온으로 식혀 품질특성을 분석하였다.

\section{미음의 색도와 $\mathrm{pH}$ 측정}

충분히 식힌 미음 $10 \mathrm{~g}$ 을 취하여 색도계(CR-300, Minolta, Tokyo, Japan)를 이용하여 3회 반복 측정하였고 그 평균값 을 Hunter's Lab scale에 의한 명도(L), 적색도(a), 황색도(b) 값으로 나타내었다. 표준백판의 $\mathrm{L}$ 값은 $97.38, \mathrm{a}$ 값은 -0.02 , $\mathrm{b}$ 값은 +1.66 이었다. $\mathrm{pH}$ 측정은 시료 $20 \mathrm{~g}$ 을 취하여 $\mathrm{pH}$ meter(Metrohm 691, Metrohm, Herisau, Switzerland)를 이용 하여 측정하였다.

\section{미음의 점도와 퍼짐성 측정}

미음의 점도를 측정하기 위해 점도계 $\mathrm{RVDV}-\Pi+$, Brookfield Engineering Lab., Inc., Middleboro, MA, USA)를 이용하여 측정하였다. Spindle No.2,3,6을 사용하였고, 각 시료는 $100 \mathrm{~mL}$ 의 용기에 담아 20 또는 $30 \mathrm{rpm}$ 으로 $60^{\circ} \mathrm{C}$ 온도를 유지하면서 측정하였다. 죽의 퍼짐성은 Line Spread Chart를 사용하여 $60^{\circ} \mathrm{C}$ 죽 $35 \mathrm{~g}$ 을 취하여 Polyethylene 원통 에 가득 채워 넣고 1 분이 지난 후 원통을 단번에 들어 올려 정확히 1 분 간 시료가 흐르도록 한 후 4 군데의 퍼진 거리를 측정하여 평균값을 구하였다(5).

\section{주사전자현미경(SEM)을 이용한 쌀알과 미음의 미세구 조 관찰}

쌀 입자와 호화된 미음의 형태는 쌀 낟알과 동결건조 시킨 미음을 절단하여 탄소 테이프 위에 고정시킨 후 scanning electron microscope(SEM; TM3000, Hitachi, Tokyo, Japan)을 이용하여 각각 2,000 배, 1,800 배 확대하여 관찰하였다.

\section{통계분석}

모든 데이터는 3 회 반복 측정하였으며, mean $\pm \mathrm{SD}$ 로 표현 하였다. 얻어진 결과를 SPSS package(version 12.0, SPSS Inc., Chicago, IL, USA)를 이용하여 다범위검정(Duncan's multiple range test)을 통하여 $\mathrm{p}<0.05$ 수준에서 유의성 있는 그룹간의 차이를 검정하였으며, 상관관계는 Pearson의 상 관계수로 나타내었다.

\section{결과 및 고찰}

\section{벼 품종별 아밀로오스, 단백질 함량 비교}

쌀로 밥을 지을 때나 가공식품을 제조할 때 맛이나 조리, 가공 상의 특성에 영향을 미치는 요인으로 전분, 단백질, 지방 등이 있다(14). 이 중에서도 전분의 아밀로오스 함량은 쌀의 조리특성과 밥의 조직감, 광택 등 식미를 결정하는
가장 중요한 요인으로서 품종들의 아밀로오스와 단백질 함량은 Table 1과 같았다(육성년도 기준). 찰벼인 화선찰이 $5.0 \%$ 로 가장 낮았고, 다른 메벼 품종들은 $18.2-19.9 \%$ 범위 를 보였으며, 고아밀로오스 벼인 고아미 4 호와 도담쌀이 각 각 $31.8,42.8 \%$ 를 나타내었다. 단백질은 전분 입자표면에 달라붙어 있으면서 전분입자를 감싸고 있다가, 수분을 흡 수하면 깨지게 되어 단백질과 전분 사이의 결합이 약하게 된다고 보고된 바 있다(15). 본 실험에 사용한 품종들은 단백질 함량이 5.5(대보)-7.3\%(한아름3호)의 범위를 나타 냈다. Juliano(12)는 이들에 의한 전분의 팽윤억제로 전분의 호화특성에 직접적으로 영향을 주어 밥의 식감과 부의 상관 을 가진다고 하였는데 미음은 수침, 마쇄, 가수 및 호화 처리를 거치므로 취반에 미치는 단백질의 영향과는 다를 수 있을 것이라 생각된다.

\section{신속점도계를 이용한 호화점도(RVA) 분석}

호화는 전분의 아밀로오스와 아밀로펙틴의 구성 비율, 전분의 구조 차이, 전분 입자의 팽윤 정도, 단백질과 지방 함량 차이 등 다양한 요인에 의해 영향을 받는 것으로 알려 져 있다(16-17). 9개 벼 품종(통일형 4개, 자포니카형 5개)의 호화특성을 신속점도 분석기(rapid viscosity analyzer; RVA) 를 이용하여 분석한 결과는 Table 2 와 같았다. 쌀가루를 물과 함께 가열하면 전분입자는 물을 흡수하여 팽윤하고 부피 증가로 인해 점성이 증가하는데(18-19), 최고점도 (peak viscosity)는 한아름4호가 213.9 RVU로 높았고, 도담 쌀이 $38.63 \mathrm{RVU}$ 로 가장 낮았다. 최저점도(trough viscosity) 는, 고아미4호가 $173.08 \mathrm{RVU}$ 로 가장 높았고 도담쌀이 32.21 RVU로 가장 낮았으며, 화선찰도 89.67 RVU로 낮았 다. 강하점도(breakdown)는 호화중의 열, 전단에 대한 저항 을 나타내는 값으로, 아밀로오스 함량과 부의 상관관계가 있다고 알려져 있는데, 고아밀로오스 품종인 도담쌀과 고 아미4호가 각각 $6.42,17.50 \mathrm{RVU}$ 로 낮았고, 한아름4호가 98.7 RVU로 높았다. 최종점도(final viscosity)는 고아미4호 가 $254.38 \mathrm{RVU}$ 를 나타내어 고아미 4 호로 만든 죽의 노화가 가장 빠를 수 있을 것으로 생각되었으며, 화선찰(109.00 $\mathrm{RVU})$ 과 한아름4호(200.80 RVU)는 다른 품종들에 비하여 노화가 느릴 것으로 판단되었다. Juliano $\mathrm{BO}(15)$ 에 의하면 아밀로오스 함량이 높을수록 전분분자들이 재결합 속도가 빨라 점도가 상대적으로 빨리 증가한다고 하였다. 또한 노 화경향을 나타내는 치반점도(setback)에서는 한아름4호, 화 선찰이 각각 $-13.2,-27.50 \mathrm{RVU}$ 로 노화가 느릴 것으로 예상 되며, 한아름3호가 $74.17 \mathrm{RVU}$ 로 노화가 가장 빨리 진행될 것으로 판단된다. 치반점도(setback)와 최종점도(final viscosity)가 낮은 한아름4호, 화선찰 등이 노화가 느린 특성 을 필요로 하는 제품 원료로 적합할 것으로 사료되며 도담 쌀은 전분체 고유의 물리적 구조와 그로 인한 영향으로 호화가 잘 되지 않는 것으로 판단되어 호화 점도 고찰에서 
Table 2. Varietal difference in pasting properties of rice flour

\begin{tabular}{cccccccc}
\hline \multirow{2}{*}{ Rice type } & Variety & \multicolumn{5}{c}{ Pasting properties (RVU) } \\
\cline { 3 - 7 } Tongil-type & Areum & $68.2 \pm 0.1^{2)(3)}$ & $176.1 \pm 1.3^{\mathrm{e}}$ & $127.3 \pm 4.0^{\mathrm{c}}$ & $48.8 \pm 5.3^{\mathrm{b}}$ & $237.8 \pm 0.4^{\mathrm{b}}$ & $61.7 \pm 0.9^{\mathrm{b}}$ \\
& Namcheon & $68.1 \pm 0.0^{\mathrm{c}}$ & $176.1 \pm 0.9^{\mathrm{e}}$ & $126.3 \pm 0.8^{\mathrm{c}}$ & $49.7 \pm 1.7^{\mathrm{b}}$ & $232.9 \pm 0.4^{\mathrm{bc}}$ & $56.9 \pm 0.5^{\mathrm{c}}$ \\
& Hanareum3 & $68.3 \pm 0.0^{\mathrm{c}}$ & $156.8 \pm 1.7^{\mathrm{f}}$ & $118.8 \pm 1.3^{\mathrm{d}}$ & $38.0 \pm 0.4^{\mathrm{d}}$ & $230.9 \pm 1.7^{\mathrm{cd}}$ & $74.2 \pm 0.0^{\mathrm{a}}$ \\
& Hanareum4 & $68.2 \pm 0.1^{\mathrm{c}}$ & $213.9 \pm 0.5^{\mathrm{a}}$ & $115.2 \pm 1.2^{\mathrm{d}}$ & $98.7 \pm 0.8^{\mathrm{a}}$ & $200.8 \pm 0.5^{\mathrm{e}}$ & $-13.2 \pm 0.9^{\mathrm{f}}$ \\
\hline Japonica-type & Unkwang & $68.2 \pm 0.1^{\mathrm{c}}$ & $186.4 \pm 1.9^{\mathrm{d}}$ & $144.6 \pm 4.0^{\mathrm{b}}$ & $41.8 \pm 2.0^{\mathrm{cd}}$ & $226.6 \pm 0.9^{\mathrm{d}}$ & $40.2 \pm 1.1^{\mathrm{d}}$ \\
& Daebo & $68.1 \pm 0.1^{\mathrm{c}}$ & $196.7 \pm 0.2^{\mathrm{b}}$ & $149.8 \pm 4.1^{\mathrm{b}}$ & $46.9 \pm 4.2^{\mathrm{bc}}$ & $235.2 \pm 0.5^{\mathrm{bc}}$ & $38.5 \pm 0.3^{\mathrm{d}}$ \\
& Goami4 & $78.0 \pm 0.5^{\mathrm{b}}$ & $190.6 \pm 1.7^{\mathrm{c}}$ & $173.1 \pm 0.0^{\mathrm{a}}$ & $17.5 \pm 1.7^{\mathrm{e}}$ & $254.4 \pm 6.1^{\mathrm{a}}$ & $63.8 \pm 4.4^{\mathrm{b}}$ \\
& Dodamssal & $79.5 \pm 0.5^{\mathrm{a}}$ & $38.6 \pm 0.5^{\mathrm{h}}$ & $32.2 \pm 0.1^{\mathrm{f}}$ & $6.4 \pm 0.5^{\mathrm{f}}$ & $48.4 \pm 0.1^{\mathrm{g}}$ & $9.8 \pm 0.7^{\mathrm{c}}$ \\
& Hwaseonchal & $68.1 \pm 0.1^{\mathrm{c}}$ & $136.5 \pm 0.4^{\mathrm{g}}$ & $89.7 \pm 1.9^{\mathrm{e}}$ & $46.8 \pm 2.2^{\mathrm{bc}}$ & $109.0 \pm 2.6^{\mathrm{f}}$ & $-27.5 \pm 2.9^{\mathrm{f}}$ \\
\hline
\end{tabular}

${ }^{1)} \mathrm{PT}$, pasting temperature.

${ }^{2)}$ Values are means \pm SD.

${ }^{3) a-g}$ Mean with same letter in column are not significantly different $(p<0.05)$

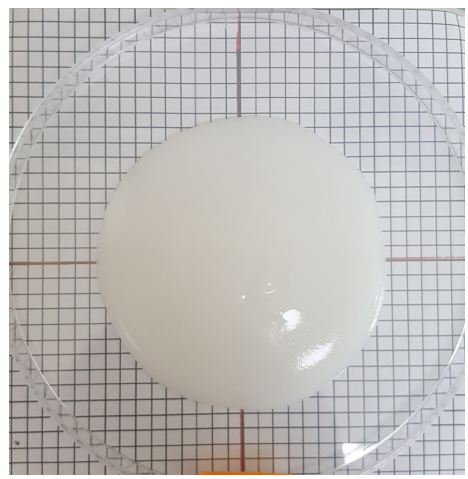

(A)

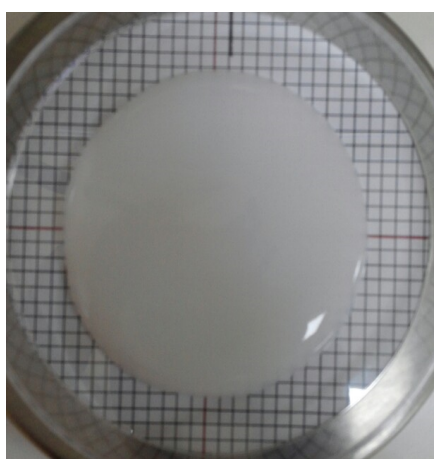

(B)

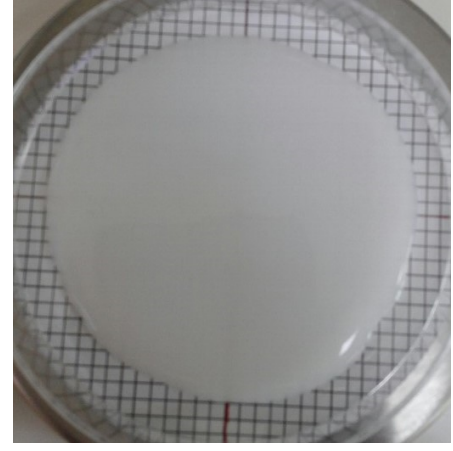

(C)

Fig. 1. Varietal difference in spreadability of the rice porridge made from (A) Dodamssal, (B) Hanareum4 and (C) Hwaseonchal.

는 일부 제외하였다. 호화개시온도(Pasting temperature)는 도담쌀 79.5, 고아미4호 78.0, 그 외 품종들은 68.1-68.3 범위 를 나타내었다. 통일형 멥쌀 4개 품종과 일반형 멥쌀 3개 품종 간에는 차이가 없었으며, 고아밀로오스 품종인 ‘고아 미4호'와 ‘도담쌀’은 멥쌀과 찹쌀에 비해서 높았다. Peak time은 화선찰벼, 한아름4호가 각각 $4.2,5.9$ 분을 나타내었 고 그 외 품종들은 6.0-6.44분을 나타내었다. 찰벼 품종들이 최고점도에 이르는 시간이 짧았고, 고아밀로오스 벼 품종 들이 다른 품종들에 비해 호화를 위한 에너지가 큰 것을 확인하였다. 호화액의 점도 변화는 호화과정 중에 용출된 아밀로오스, 전분입자, 팽윤된 입자로부터 용출된 직선상 의 고분자에 의해 기인되는 것으로 판단하였다. 6개 멥쌀 (찹쌀, 고아밀로오스 제외) 품종 중에서 한아름4호가 최고 점도 및 강하점도가 다른 품종들보다 높았고, 치반점도는 낮았다. 찹쌀(화선찰)은 멥쌀에 비하여 최고, 최저, 최종 및 치반점도가 낮았는데, 이는 선행연구 결과와 유사하였 다(20). 찹쌀 호화액의 최고점도는 호화된 아밀로펙틴의 수화정도와 탈 분지정도에 의해 영향을 받는데 이는 아밀로
오스가 용출될 수 없기 때문으로 생각된다. 반면, 쌀가루의 호화점도는 아밀로오스 함량이 높을수록 최고, 최저 및 최 종점도가 낮고, 치반점도가 높은 것으로 알려져 있으나 (20-21), 본 시험에서 이용한 고아밀로오스 품종인 '고아미 4호'와 '도담쌀'의 호화점도 특성 차이가 크게 나타났다. 이는 전분의 구성 비율뿐만 아니라 전분의 구조적 차이, 기타 요인 등 요인 구명을 위한 추가적인 연구가 이루어져 야 할 것으로 사료되었다. 이러한 품종별 쌀가루의 호화점 도 특성 차이가 쌀미음의 주요 가공특성인 퍼짐성과 점도에 영향을 미칠 것으로 예상되었다.

\section{품종별 미음의 색도, $\mathrm{pH}$ 비교}

벼 품종에 따른 미음을 제조한 후 색도와 $\mathrm{pH}$ 를 분석한 결과 Table 3과 같이 품종간의 유의적인 차이가 나타났다. 색도 측정은 확산 조명이 시료 표면에 조사되고 표면에서 반사된 빛을 센서로 감지하는데 품종에 따른 쌀알의 구조적 인 특징, 공극의 양 등이 다르므로 이와 같은 차이가 나는 것으로 판단되었다. 명도값에서는 아밀로오스 함량(찰벼, 
Table 3. Varietal difference in the Hunter's color, $\mathrm{pH}$ value of rice porridge

\begin{tabular}{|c|c|c|c|c|c|}
\hline \multirow{2}{*}{ Rice type } & \multirow{2}{*}{ Variety } & \multicolumn{3}{|c|}{ Hunter's color of rice porridge } & \multirow{2}{*}{$\begin{array}{c}\mathrm{pH} \\
\text { value }\end{array}$} \\
\hline & & Lightness $\left(\mathrm{L}^{*}\right)$ & Redness $\left(a^{*}\right)$ & Yellowness $\left(b^{*}\right)$ & \\
\hline \multirow[t]{4}{*}{ Tongil-type } & Areum & $65.27 \pm 0.69^{1(2) 2}$ & $-1.31 \pm 0.05^{c}$ & $-4.20 \pm 0.17^{\text {cd }}$ & $7.09 \pm 0.01^{b}$ \\
\hline & Namcheon & $63.04 \pm 0.74^{\mathrm{de}}$ & $-1.15 \pm 0.07^{b}$ & $-4.09 \pm 0.23^{\mathrm{c}}$ & $6.94 \pm 0.00^{\mathrm{d}}$ \\
\hline & Hanareum3 & $65.56 \pm 0.76^{\mathrm{bc}}$ & $-1.41 \pm 0.06^{\mathrm{d}}$ & $-3.64 \pm 0.24^{b}$ & $6.78 \pm 0.01^{\mathrm{f}}$ \\
\hline & Hanareum4 & $64.06 \pm 2.33^{\mathrm{cd}}$ & $-1.09 \pm 0.05^{\mathrm{ab}}$ & $-4.88 \pm 0.21^{\mathrm{e}}$ & $6.96 \pm 0.01^{\mathrm{cd}}$ \\
\hline \multirow[t]{5}{*}{ Japonica-type } & Unkwang & $61.59 \pm 0.82^{\mathrm{e}}$ & $-1.85 \pm 0.07^{\mathrm{f}}$ & $-2.62 \pm 0.44^{\mathrm{a}}$ & $7.16 \pm 0.01^{\mathrm{a}}$ \\
\hline & Daebo & $59.32 \pm 0.92^{\mathrm{f}}$ & $-1.44 \pm 0.08^{d}$ & $-4.52 \pm 0.33^{\mathrm{d}}$ & $7.07 \pm 0.02^{b}$ \\
\hline & Goami4 & $67.09 \pm 0.33^{b}$ & $-2.06 \pm 0.02^{\mathrm{g}}$ & $-2.65 \pm 0.34^{\mathrm{a}}$ & $6.98 \pm 0.01^{\mathrm{c}}$ \\
\hline & Dodamssal & $71.12 \pm 0.74^{\mathrm{a}}$ & $-1.65 \pm 0.04^{e}$ & $-4.41 \pm 0.08^{\text {cd }}$ & $6.88 \pm 0.01^{\mathrm{e}}$ \\
\hline & Hwaseonchal & $52.90 \pm 2.10^{g}$ & $-1.01 \pm 0.10^{\mathrm{a}}$ & $-5.59 \pm 0.15^{\mathrm{f}}$ & $6.61 \pm 0.00^{g}$ \\
\hline
\end{tabular}

\footnotetext{
${ }^{1)}$ Values are means \pm SD
}

${ }^{2) a-g}$ Mean with same letter in column are not significantly different $(\mathrm{p}<0.05)$.

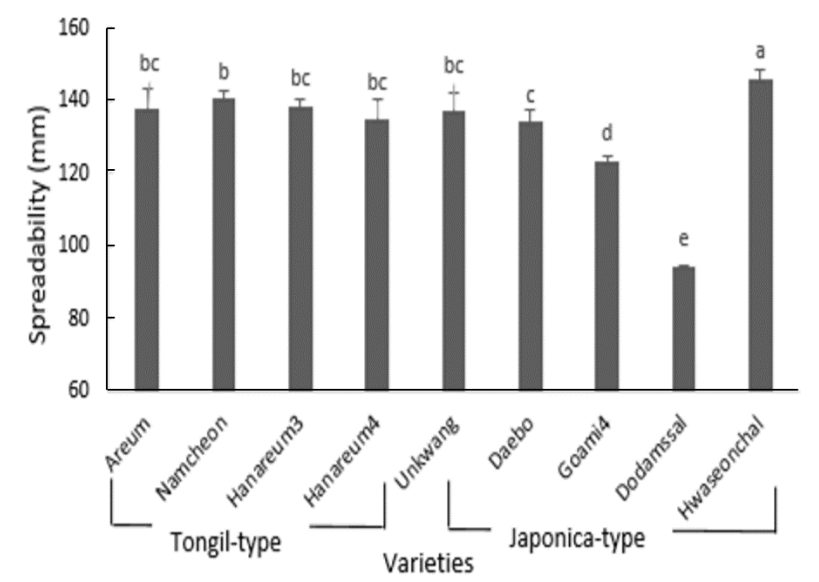

Fig. 2. Varietal difference in spreadability of the rice porridge made from 4 tongil-type and 5 japonica-type varieties. Bars with the different letters are significantly different at the $5 \%$ level.

일반메벼, 고아밀로오스벼 등)에 따른 유의적인 차이가 보 였으나, 시료수를 고려했을 때, 더 많은 품종에 대한 실험이 필요하다고 생각되었다. 고아밀로오스 품종인 '도담쌀'과 '고아미 4 호'의 L 값이 각각 $71.12,67.09$ 로 높았고, '화선찰' 이 52.90으로 가장 낮았다. a 값은 '고아미4호' -2.06 에서 '화선찰' -1.01 의 범위였고, $\mathrm{b}$ 값은 '화선찰' -5.59 에서 일반 형 멥쌀인 '운광' -2.62 의 범위였다. 쌀미음의 $\mathrm{pH}$ 를 측정한 결과 $\mathrm{pH}$ 6.61(화선찰)에서 7.16(운광)의 범위를 나타내었는 데 이는 Hwang 등(22)의 일반쌀죽의 $\mathrm{pH}$ 가 6.51 이었다는 연구결과와 유사하였다.

\section{품종별 미음의 점도, 퍼짐성 비교}

품종별 미음 제조 후 점도와 퍼짐성은 각각 Table 4, Fig. 2 와 같았다. 점도는 품종별로 spindle No.를 달리하여 측정 하였는데 도담쌀(고아밀로오스)은 No.6, $20 \mathrm{rpm}$, 고아미4 호(고아밀로오스)는 No.3, $20 \mathrm{rpm}$ 조건에서 측정하였으며
Table 4. Viscosity of the porridge made from different rice varieties

\begin{tabular}{ccccc}
\hline \multirow{2}{*}{ Rice type } & \multirow{2}{*}{ Variety } & \multicolumn{3}{c}{ Viscosity (cP, spindle number/rpm) } \\
\cline { 3 - 5 } Tongil-type & Areum & $758.7 \pm 15.1^{1 / 2)}$ & - & - \\
& Namcheon & $718.0 \pm 18.0^{\mathrm{ab}}$ & - & - \\
& Hanareum3 & $792.7 \pm 63.1^{\mathrm{a}}$ & - & - \\
& Hanareum4 & $722.7 \pm 20.7^{\mathrm{ab}}$ & - & - \\
\hline Japonica-type & Unkwang & $672.0 \pm 13.2^{\mathrm{bc}}$ & - & - \\
& Daebo & $634.7 \pm 37.7^{\mathrm{c}}$ & - & - \\
& Goami4 & - & $2,555 \pm 99$ & - \\
& Dodamssal & - & - & $31,150 \pm 2,899$ \\
& Hwaseonchal & $561.4 \pm 1.9^{\mathrm{d}}$ & - & - \\
\hline
\end{tabular}

${ }^{1)}$ Values are means \pm SD.

${ }^{2}$ Mean with same letter in column are not significantly different $(\mathrm{p}<0.05)$.

Viscosity (cP) of rice porridge is measured by RVDV- $\Pi$ model. Diameter of spindle No.2,3, and 6 is $2.47 \mathrm{~mm}, 3.40 \mathrm{~mm}$, and $1.95 \mathrm{~mm}$, respectively.

나머지 품종(멥쌀, 찹쌀)들은 No.2, $30 \mathrm{rpm}$ 조건으로 측정하 였다. 도담쌀은 $31,150 \mathrm{cP}$, 고아미 4 호는 $2,555 \mathrm{cP}$, 화선찰은 $561.35 \mathrm{cP}$ 를 나타내었으며 나머지 품종들은 $561.4-758.7 \mathrm{cP}$ 범위를 보였다. 먼저, 도담쌀로 만든 미음의 점도가 현저히 높은 것은 아밀로오스들이 치밀하게 밀집된 구조인 고아밀 로오스 품종의 전분체 특성으로 인해 물리적으로 수화 및 호화가 잘 되지 않기 때문에 전분립들이 잘 풀어지지 않는 다고 판단되었다. 다만, 고아미 4 호도 고아밀로오스 품종인 점을 감안하면 도담쌀 품종 고유의 특성인 전분체의 구성물 질의 조성과 함량, 결합강도가 다른 고아밀로오스 품종과 는 다소 다를 것으로 예상되었다. 화선찰과 같은 아밀로펙 틴 함량이 높은 품종(점도를 증가시키는 아밀로오스 함량 이 낮음)은 전분의 수화 및 호화가 용이하여 금새 풀어져 낮은 점도를 나타내었는데, 일반 메벼(대보)의 점도도 다소 

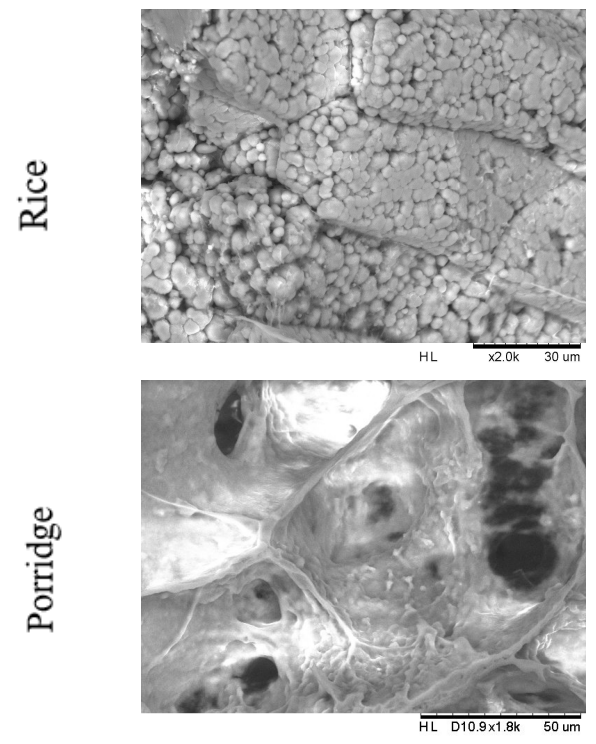

(A)
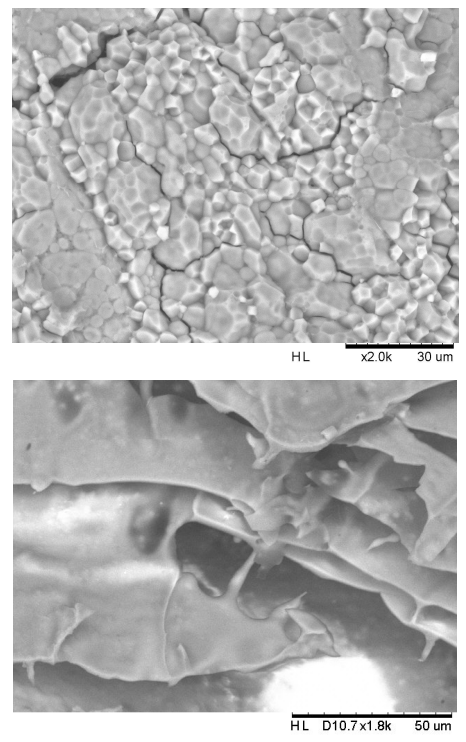

(B)
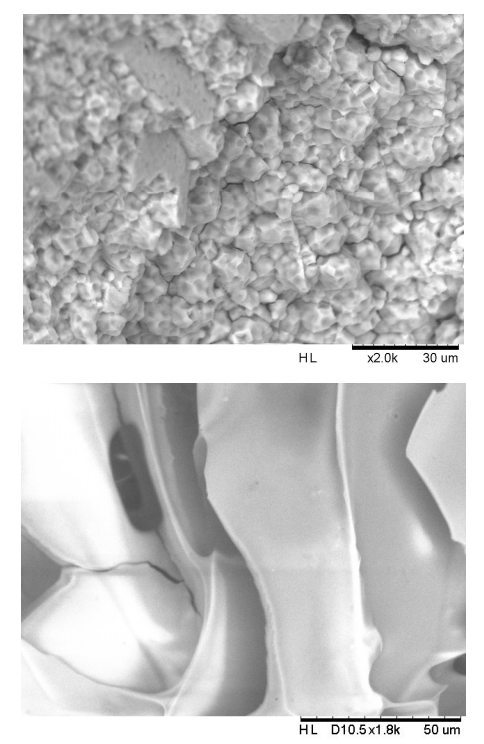

(C)

Fig 3. Scanning electron microscope images of rice kernel and porridge made from (A) Dodamssal, (B) Hanareum4 and (C) Hwaseonchal.

낮은 것으로 보아 미음의 점도에 아밀로펙틴뿐만 아니라 단백질, 지질, 식이섬유 등 다른 성분들이 영향을 주는 것으 로 생각되었다. 쌀의 아밀로오스 함량 증가에 따라 미음의 점성이 증가하는 경향을 보였는데 이는 주로 용출 아밀로오 스에 인한 것으로 판단되었고 세포벽 등의 파괴로 용해성 물질인 저분자 물질, 단백질, 회분 등 용출물도 점도에 영향 을 주었다고 판단되었다. Lee 등(23)은 타락죽 선행연구에 서 가열과정 중 amylose-lipid 복합체 형성은 amylose의 용 출을 방해하고 전분입자의 팽윤을 저해, 전분의 수분결합 능력을 감소시켜 죽의 점도에 영향을 미칠 수 있다고 하였 다. 따라서 미음과 같은 흰쌀로 만든 죽에서 참기름과 같은 지방질 부 원료의 첨가에 따른 점도 변화가 가능할 것으로 생각되었다. 한편, 퍼짐성은 점도와는 반대로 도담쌀이 $94.43 \mathrm{~mm}$ 로 가장 낮았으며, 고아미4호가 $123.55 \mathrm{~mm}$ 를 나 타내었고, 그 외 품종들은 134.10-140.66 mm 범위를 나타내 었고, 화선찰이 $146.03 \mathrm{~mm}$ 로 가장 높았다.

\section{쌀 낟알과 미음의 초미세구조 관찰}

주사전자현미경(SEM)으로 쌀 낟알의 단면 및 호화 형태 를 관찰한 결과는 Fig. 3 과 같았다. 일반적으로 쌀의 전분 직경은 2-10 $\mu \mathrm{m}$ 로 곡류전분 중 가장 작은 입자로 알려져 있다. 본 연구의 쌀 낟앋 단면 관찰에서, 다각형의 전분립들 이 모여 찌그러진 구나 타원형 등 불규칙한 모양의 전분체 를 이루고 있었으며 전분체의 크기는 같은 품종 내에서도 다양하였다. 고아밀로오스 품종들의 경우에는 각각의 전분 체의 물리적인 구조(전분체를 이루는 전분립들의 강한 결 합)로 인해 전분립들의 분리가 어려운 특성을 나타내었고, 이와 같은 특성이 쌀의 수화나 호화, 가공과정에서 영향을 줄 것으로 판단되었다. 또한 쌀의 전분입자는 호화가 진행
되면서 다면체의 표면이 부드러워지며 전분입자들이 분해 되는 양상을 확인하였다. 품종별 미음의 초미세구조에서는 모든 품종들이 호화로 인해 전분입자가 붕괴되어 입자형태 를 관찰할 수 없었고 대부분의 표면이 매끄러웠다. 찰벼인 화선찰 미음의 표면이 특히 매끄러웠으며 고아밀로오스 품종인 도담쌀로 만든 미음에서는 잘 풀어지지 않고 다소 형태를 유지하고 있는 전분립이 관찰되었고 같은 고아밀로 오스 벼 품종이지만 고아미4호로 만든 미음은 다소 잘 풀어 짐을 확인하였다(data not shown). 이와 같은 원료의 특성은 체내로 섭취 시 소화 흡수에 영향을 줄 수 있을 것으로 사료되었다.

\section{미음 품질 관련 인자의 상관관계 분석}

본 연구에서 고려된 미음의 품질 관련 인자들 간의 관계 를 알아보기 위해 상관관계를 분석하였다(Table 5). pasting temperature는 breakdown $(\mathrm{R}=-0.714, \mathrm{p}<0.05)$, 퍼짐성 $(\mathrm{R}=-0.887, \mathrm{p}<0.01)$ 과 부의상관을, 미음의 점도 $(\mathrm{R}=0.760$, $\mathrm{p}<0.05)$ 와는 정의상관을 나타내었다. 최고점도는 최저점도 $(\mathrm{R}=0.876, \mathrm{p}<0.01)$, 최종점도 $(\mathrm{R}=0.868, \mathrm{p}<0.01)$, 퍼짐성 $(\mathrm{R}=0.719, \mathrm{p}<0.05)$ 과 정의상관을, 미음의 점도 $(\mathrm{R}=-0.894$, $\mathrm{p}<0.01)$ 와 부의상관을 나타내었다. 최종점도는 setback $(\mathrm{R}=0.699, \mathrm{p}<0.05)$ 과는 정의상관을, 미음의 점도 $(\mathrm{R}=-0.777$, $\mathrm{p}<0.05)$ 와는 부의상관을 나타내었다. 미음의 $\mathrm{L}$ 값은 미음의 퍼짐성 $(\mathrm{R}=-0.732, \mathrm{p}<0.05)$ 과 부의상관을 나타내었고, 미음 의 퍼짐성은 미음의 점도 $(\mathrm{R}=-0.938, \mathrm{p}<0.01)$ 와는 부의상관 을 나타내었다. 즉, 쌀 품종에 따라 특성이 다르지만, 보통 고아밀로스 품종들일수록(아밀로오스 함량이 증가할수록) 호화를 위한 필요 에너지가 높아 pasting temperature가 높아 지는 경향을 보였다. Pasting temperature가 높은 품종일수록 
Table 5. The correlation between viscosity of porridge and quality factors in 9 rice varieties.

\begin{tabular}{|c|c|c|c|c|c|c|c|c|}
\hline \multirow{2}{*}{ Factor } & \multicolumn{6}{|c|}{ Rapid viscosity analyzer } & \multirow{2}{*}{$\mathrm{L}$ value } & \multirow{2}{*}{$\begin{array}{l}\text { Spread- } \\
\text { ability }\end{array}$} \\
\hline & $\mathrm{PT}^{1)}$ & Peak & Trough & Breakdown & Final & Setback & & \\
\hline Peak & $-0.591^{\mathrm{NS} 2)}$ & - & & & & & & \\
\hline Trough & $-0.308^{\mathrm{NS}}$ & $0.876^{\star * 3)}$ & - & & & & & \\
\hline Breakdown & $-0.714^{*}$ & $0.648^{\mathrm{NS}}$ & $0.201^{\mathrm{NS}}$ & - & & & & \\
\hline Final & $-0.425^{\mathrm{NS}}$ & $0.868^{* *}$ & $0.928^{* *}$ & $0.297^{\mathrm{NS}}$ & - & & & \\
\hline Setback & $0.022^{\mathrm{NS}}$ & $0.251^{\mathrm{NS}}$ & $0.546^{\mathrm{NS}}$ & $-0.354^{\mathrm{NS}}$ & $0.699^{*}$ & - & & \\
\hline$L$ value & $0.657^{\mathrm{NS}}$ & $-0.336^{\mathrm{NS}}$ & $-0.195^{\mathrm{NS}}$ & $-0.376^{\mathrm{NS}}$ & $-0.028^{\mathrm{NS}}$ & $0.429^{\mathrm{NS}}$ & - & \\
\hline Spreadability & $-0.887^{* *}$ & $0.719^{*}$ & $0.544^{\mathrm{NS}}$ & $0.601^{\mathrm{NS}}$ & $0.568^{\mathrm{NS}}$ & $0.073^{\mathrm{NS}}$ & $-0.732^{*}$ & - \\
\hline Viscosity & $0.760^{*}$ & $-0.894^{* *}$ & $-0.786^{* *}$ & $-0.576^{\mathrm{NS}}$ & $-0.777^{*}$ & $-0.227^{\mathrm{NS}}$ & $0.593^{\mathrm{NS}}$ & $-0.938^{* *}$ \\
\hline
\end{tabular}

${ }^{1)} \mathrm{PT}$, pasting temperature.

2)NS, not significant.

3)* and ${ }^{* *}$, significant at $\mathrm{p}<0.05$ and $\mathrm{p}<0.01$.

미음을 만들었을 때 점도가 높을 수 있다는 결과를 나타내 었고(정의상관), 미음의 점도가 높을수록 미음의 퍼짐성은 낮게 나타났다. 또한, 원료 쌀가루의 최고점도가 높을수록 미음의 점도는 낮아질 수 있다는 결과를 도출하였다(부의 상관).

\section{요 약}

본 연구는 벼 품종에 따른 미음 가공특성을 구명하기 위하여 국립식량과학원에서 육성한 9개 벼 품종의 호화점 도 특성과 미음의 색도, $\mathrm{pH}$, 점도 및 퍼짐성을 측정하고, 초미세구조를 관찰하였다. 신속점도계를 이용한 호화 점도 (페이스팅) 분석에서, 치반점도는 한아름4호, 화선찰이 각 각 -45.84 및 -27.50 RVU, 최종점도는 화선찰, 한아름4호가 각각 $109.00,213.42 \mathrm{RVU}$ 로 미음죽의 노화가 다른 품종들 에 비해 느릴 것으로 판단된다. 쌀 낟알과 미음의 미세구조 를 주사현미경(SEM)으로 관찰하였는데, 쌀알은 다각형의 전분립으로 구성된 구 형태의 전분체와 이러한 전분체로 구성된 전분세포로 구성되어 있었다. 도담쌀은 구 모양의 전분체가 관찰되었고 다른 품종들에 비해 빈 공간이 더 많았으며, 한아름4호는 일반 멥쌀의 형태와 같은 다각형의 전분립을 확인하였고, 화선찰벼는 전분체를 구성하는 전분 립들의 부서짐이 많은 것을 관찰하였다. 그리고 이 품종들 로 만든 미음죽 호화양상은 품종별로 달랐는데 이는 주로 아밀로오스 함량 차이에 기인하는 것으로 판단되나, 같은 고아밀로오스 품종이라 하더라도 도담쌀에 비해 고아미4 호는 잘 풀어지고 호화가 잘 되는 것으로 나타나는 바(data not shown), 이에 대한 추가적인 연구가 필요하다 하겠다. 품종별 미음 제조 후, 관능검사에서 통일형(초다수성) 벼 품종과 자포니카 벼 품종들의 차이가 뚜렷하게 나타나지 않아 초다수성 벼 품종으로 자포니카 벼 품종을 대체할
수 있을 것으로 판단하였다(data not shown). 또한 아밀로오 스 함량 차이에 따른 벼 품종들 간의 점도 차이가 확연하게 나타났는데 아밀로오스가 없는 찰벼 품종은 미음죽의 점도 를 낮추고, 고아밀로오스 품종들은 미음죽의 점도를 높였 다. 통일형(초다수성 벼)을 포함한 일반메벼 품종들의 점도 는 찹쌀과 고아밀로오스 품종들로 만든 미음의 중간정도를 보였으며 품종간의 유의한 차이는 없었다. 요컨대, 통일형 품종은 일반쌀 품종에 비해 밥용으로 식미가 나쁜 것으로 알려져 있으나, 미음에 대한 가공적성 평가 결과, 통일형 쌀 품종과 일반쌀 품종 간에 품질 차이가 없었다. 쌀미음의 점도와 퍼짐성은 쌀미음의 품질을 결정하는 중요한 요소이 며 9개 품종(통일형 4개 품종, 일반형 5개)의 쌀미음 가공적 성을 평가한 결과, 고아밀로오스(31.8\%-42.8\%) 쌀 품종들 은 점도가 높아(낮은 퍼짐성) 걸쭉하였고, 저아밀로오스 (5.0\%)인 찹쌀 품종은 낮은 점도(높은 퍼짐성)로 유동적이 었다. 중간정도의 특성을 가진 멥쌀(18.2\%-19.9\%) 품종들 이 쌀미음에 적합한 것으로 나타났다. 멥쌀 품종들 중에서 생태형(통일형/일반형)에 따른 쌀미음의 점도와 퍼짐성에 서 차이가 없었다.

\section{감사의 글}

본 연구는 농촌진흥청 연구사업(과제번호: PJ01026703) 의 지원에 의해 이루어진 것이며 이에 감사드립니다.

\section{References}

1. Yoon SJ, Hawer WD (2008) A study on calorie and proximate components of traditional Korea gruel. J Korean Soc Food Sci Nutr, 37, 879-885 
2. Cho MS, Lee KR (2011) A study on changes in the cooking process of gruel in cook books written during last 100 years. Korean J Food Nutr, 24, 589-601

3. Korea Agro-Fisheries \& Food Trade Corporation Food Information Statistics System. http://www.atfis.or.kr /sales/M002020000/view.do?searchItem =CD00000595 \&searchDivision $=$ CD00000601\&searchCompany $=2 \&$ se archYear $=2017 \&$ searchQuarter $=$ T\&selectAccessHistory Idx $=$ (assessed August 2017)

4. Lee HJ, Pak HO, Lee SY (2005) A study of optimum conditions in preparing gruel with black bean germ sprout source. Korean J Food Nutr, 18, 287-294

5. Kim JM, Suh DS, Kim YS, Kim KO (2004) Physical and sensory properties of rice gruels and cakes containing different levels of ginkgo nut powder. Korean J Food Sci Technol, 36, 410-415

6. Shin ES, Lee KA, Lee HK, Kim KBWR, Kim MJ, Byun MW, Lee JW, Kim JH, Ahn DH, Lyu ES (2008) Effect of grain size and added water on quality characteristics of abalone porridge. J Korean Soc Food Sci Nutr, 37, 245-250

7. Lee GD, Kim HG, Kim JG, Kwon JH (1997) Optimization for the preparation conditions of instant rice gruel using oyster mushroom and brown rice. Korean J Food Sci Technol, 29, 737-744

8. Han KH, Oh JC, Ryu CH (2004) A study on the optimization for preparation conditions of germinated brown rice gruel. J Korean Soc Food Sci Nutr, 33, 1735-1741

9. Hong II, Choi SK (2012) A study on the development of burdock gruel. Korean J Culinary Res, 20, 18-26

10. Lee JH, Seo HS, Kim SH, Hwang IK (2005) Soaking properties and quality characteristics of Korean white gruel with different blending time of high-dietary fiber rice 'Goami 2'. Korean J Food Cookery Sci, 21, 927-935

11. Gouk SY, Han JH (2010) Strategy for developing rice processing industry. Korea rural economic institute, Naju, Korea, p 117

12. Juliano BO (1985) Polysaccharide, proteins, and lipids. In: Rice Chemistry and Technology, Juliano BO (Editor), AACC, St Paul, MN, USA, p 443-524
13. Sim EY, Chung SK, Cho JH, Woo KS, Park HY, Kim HJ, Oh SK, Kim WH (2015) Physicochemical properties of high-amylose rice varieties. Food Eng Prog, 19, 392-398

14. Sim EY, Park HY, Kim MJ, Lee CK, Jeon YH, Oh SK, Wom YJ, Lee JH, Ahn EK, Woo KS (2017) Studies on the palatability and texture of Korean rice cultivars for the cooked-rice processing. Korean J Food Nutr, 30, 880-888

15. Chiang PY, Yeh AI (2002) Effect of soaking on wet-milling of rice. J Cereal Sci, 35, 85-94

16. Beleia A, Varriano-Marston E, Hoseney RC (1980) Characterization of starch from pearl millets. Cereal Chem, 57, 300-303

17. Fitzgerald MA, Martin M, Ward RM, Park WD, Shead HJ (2003) Viscosity of rice flour: A rheological and biological study. J Agric Food Chem, 51, 2295-2299

18. Yoon MR, Oh SK, Lee JH, Kim DJ, Choi IS, Lee JS, Kim CK (2012) Varietal variation of gelatinization and cooking properties in rice having different amylose contents. Korean J Food Nutr, 25, 762-769

19. Choi HC (2002) Current status and perspectives in varietal improvement of rice cultivars for high-quality and value-added products. Korean J Crop Sci, 47, 15-32

20. Yoon MR, Chun AR, Oh SK, Ko Sh, Kim DJ, Hong HC, Choi IS, Lee JH (2011) Physicochemical properties of endosperm starch and breadmaking quality of rice cultivars. Korean J Crop Sci, 56, 219-225

21. Rho ES, Ahn SY (1989) Texture of cooked rice and molecular weight distribution of rice amylose. Korean J Food Sci Technol, 21, 486-491

22. Hwang IG, Yang JW, Kim JY, Yoo SM, Kim GC, Kim JS (2011) Quality characteristics of saccharified rice gruel prepared with different cereal koji. J Korean Soc Food Sci Nutr, 40, 1617-1622

23. Lee GC, Kim SJ, Koh BK (2003) Effect of roasting condition on the physicochemical properties of rice flour and the quality characteristics of Tarakjuk Korean J Food Sci Technol, 35, 905-913 